\title{
A Model Based on the Theory of Evolution as a Means of Explaining the Political Process in Democracies
}

\author{
Frank Daumann
}

*Corresponding Author: Frank Daumann, Germany

\begin{abstract}
The New Political Economy analyses the political events mainly from a neoclassical and welfare economic point of view and therefore remains in a static perspective based on equilibrium situations. In this paper the author tries to emphasize the procedural character of political events by referring to elements of the theory of evolution.

For this purpose, the individualist method for explaining social phenomena will be illustrated and supplemented by evolutionary elements. The application of this expanded socio-theoretical method allows a theoretical understanding of the political process and therefore can be used as an analytical reference for the political events within a democracy.
\end{abstract}

\section{INTRODUCTION}

The comprehensive claim for validity of the neoclassical paradigm can be shown perfectly by the example of the New Political Economy or the Economic Theory of Policy. The political process attracted many scientists ${ }^{1}$ who tried to explain the political events by using economic theories ${ }^{2}$. The model of competing parties is common to these theories; this model was developed by Downs who transferred Hotelling's model of spatial competition (Hotelling, 1929) to the political events of a representative democracy (Kirsch, 1974; Dinkel, 1977). Besides that, the New Political Economy examines log rolling (Buchanan, 1975), the aggregation of individual preferences (Arrow, 1963), the behaviour of associations (Olson, 1965) and bureaucracy (Niskanen, 1971) and problems of shape and origin of constitutions (Buchanan, 1975).

The New Political Economy however analyses the political events mainly from a neoclassical and welfare economic point of view and therefore remains in a static perspective based on equilibrium situations. In this essay the author tries to emphasize the procedural character of political events by referring to elements of the theory of evolution.

For this purpose, the individualist method for explaining social phenomena will be illustrated and supplemented by evolutionary elements. The application of this expanded socio-theoretical method allows a theoretical understanding of the political process and therefore can be used as an analytical reference for the political events within a democracy.

\section{Methodological Foundation}

\subsection{Specification of the Underlying Socio-Theoretical Approach of Explanation}

The socio-theoretical methodology distinguishes between collective and individualist methods (Vanberg, 1975). Whereas the collective approaches are not suitable to explain social phenomena, the individualist approaches prove to be appropriate in explaining these phenomena with the presumed emergent features. The individualist method again can be designed in a reductionist or institutional way. In the case of a reductionist approach the individualist method is enriched with psychologybased theories about human behaviour.

\footnotetext{
${ }^{1}$ An overview of competing theoretical approaches to explain the political process is given by Frey (1979).

2 The first approaches were given by Schumpeter (1942) and Downs (1957).
} 
The main feature of non-reductionist or institutionalist approaches on the other side is the construction of the explanans with a general law which includes the principle of rationality 3 such that these approaches gain a decision logic character.

In this essay the situation logic approach mainly based on Popper was chosen from the given variety of individualist social theoretic approaches.

Popper $(1969$, p. 120) tries to overcome the subjective-understanding method favoured by Weber (1976, p. 3; 1973, p. 428) and v. Hayek (1942, pp. 283) and to replace it by the objectiveunderstanding method. With this method he renounces recourse to psychological theories (Popper, 1980, pp. 112) because these are mainly regarded in a trivial way (Popper, 1980, p. 117; 1974, p. 119f.).

The situation logic approach which was forwarded by students of Popper (Watkins, 1952/53;Jarvie, 1974) was designed to explain the actions of individuals completely solely with respect to the situation (Popper, 1969, p. 120). Beside singular clauses designed to grasp the situation, the explanansis enriched with the principle of rationality as a general law because of the supposed rational action of the individual (Popper, 1969, p. 110; 1973, p. 199). The explanans must include the subjective interpretation of the given situation, the goals and the theories of the individual acting beyond the situative variables (Popper, 1973, p. 199). Finally, the explanandum can be derived as the logic result of the given situative and objectively accessible circumstances (Popper, 1969, p. 120).

The explanation of the political process does not afford an analysis of the actions of discrete individuals or a detailed explanation ${ }^{4}$; on the contrary the given task demands an abstraction from specific features of individual behaviour and a centralisation of typical dispositions as the main part of the analysis, although this method is known to reduce the level of the empirical science.

A method which refers to typical individuals is the Explanation in Principle based on the situation logic approach. In this context the author agrees with Watkins's method of Explanation in Principle (Watkins, 1952/53, pp. 31; Graf, 1978, pp. 75).

Referring to the demands of the deductive-nomologic pattern of explanation the explanans is to be shaped as follows, with respect to Hempel (1977, p. 201; Koertge, 1975, p. 440):

- the individual I is located in situation $\mathrm{S}$ (description of the situation)

- the individual I acts in a rational way (principle of rationality) and

- in the situation $\mathrm{S}$ it is rational to commit action A (analysis of the situation).

The principle of rationality is characterized by the fact that dispositions of individuals reoccur in the same way whenever any individual concerned has knowledge of the same amount of information and all logic implications for his behaviour (Watkins, 1952/53, p. 40).

The description of the situation contains the individual goals and the subjective theories of the person acting as well as his subjective point of view of the situation. Since the explanation of Watkins (1952/53, p. 35) basically requires a limitation to typical dispositions and the neglect of personal differences, especially non-typical features of behaviour and idiosyncrasies, individual goals, subjective theories and subjective perspectives are identical with the contents which are regarded typical.

In this context it must be stated that it is difficult to define the term typical in an adequate way and therefore allows an intervention of the subjective-understanding method ${ }^{5}$. Thus it is necessary to interpret the given statements considering the fact that specific goals, theories and perspectives of the situation which are supposed to be typical are associated with the individuals; these goals, theories,

\footnotetext{
${ }^{3}$ Vanberg(1975, p. 84) joins the approaches mentioned in the so called Action Theory in which the explanation of human actions is based on intentionality, i.e. the rationality of the purpose.

${ }^{4}$ The terms Explanation in Detail and Historic Explanation are commented by Watkins (1952/53, pp. 30).

${ }^{5}$ Additionally, the principle of rationality is taken away from falsification in the situation logic approach, because falsification by means of basic clauses means that the hypotheses are corrected as far as the situative variables, the goals, or the subjective theories are concerned. See Watkins(1978, p. 37), and Popper (1967).
} 
and perspectives of the situation however do not necessarily occur in the totality of the group. In spite of this, these restrictions seem acceptable because the aim is to explain structures or patterns 6 instead of explaining or predicting single events.

\subsection{Completion of the Method by Adding Elements of the Theory of Evolution}

The requirements of an evolutionary theory must also be considered within the methodical position chosen. This means that an evolutionary theory must be designed in a procedural and historically irreversible way and it must be suitable to explain the forthcoming of novelties ${ }^{7}$ and their influences in an abstract way.

The procedural character demands a perspective which takes into consideration the time passing by. Thus the amount of explanation given by a static survey is not sufficient because of changes usually taking place during a certain period of time or just because of time; and these changes are subject of the investigation (Daumann, 1993, pp. 37).

The demand for historical irreversibility excludes the repetition of the process passing by. Changes within a sequence of time are to be regarded as the basis for future developments; these developments however cannot be determined in a way that the results of the changes are known in advance, just by knowledge of a certain development.

Furthermore, it must be the task of an evolutionary theory to explain the factors which cause novelties and the consequences of these novelties in an endogenous way. The grasping and endogenous explanation of all criteria however mean the creation of a total model of the world; therefore it is necessary to restrict oneself to those criteria that are indispensable in order to find an answer to the problems given. Particularly it is not the aim of this approach to find out psychological criteria of the attitude of individuals towards novelties.

The Principle of Cognitive Creation 8 offers a possibiliy of considering the demands expected from an evolutionary theory. Therefore, human perceptions are the result of an autonomous mental interpretation. This interpretation can vary as time goes by even if the given situation remains stable while new possibilities of action are generated of which the individuals subjectively have not been aware of before (Hesse, 1990, p. 63).

In the chosen method of situation logic, the individual takes subjective theories as a basis and applies these as technology in the sense of a means-ends-relation. The principle of cognitive creation now can be adapted with the situation logic approach by means of the construction of subjective theories in a creative way. In addition to the theories which already have been tested individually as far as their technological contents are concerned the individual is able to outline creative theories as a means to solve problems. The transposition of creative theories leads to novelties and therefore is responsible for the evolution.

Because of the current screening of these subjective theories the entire individual knowledge is changed irreversibly. Thus the individual passes through processes of learning which can lead to a variation of the subjective rational action as time goes by. An individual will not necessarily repeat an action in the same way, if he applies the principle of rationality, because his potential of information changes continuously.

The understanding of the subjective theories as variable as far as time is concerned guarantees the consideration of the demands of procedurality and historic irreversibility of the analysis.

\footnotetext{
${ }^{6}$ Patterns only exclude specific results and therefore lead to a limitation of the maximum amount of explananda; see Hayek (1967), and Graf (1978).

7"A novelty is the introduction of a possibility of action which has not been applied before by an individual or by a group of individuals in the given context." Witt (1987, p. 18). Also see Koertge (1975, pp. 451), who distinguishes between combinatorial novelty, emergent novelty, and spontaneous novelty.

${ }^{8}$ Hesse (1990, p. 64) describes the Principle of Cognitive Creation as follows: "Perception consists of the creation of a system. Perceptions are speculations on interrelations, and the human brains offer alternative creations of a system spontaneously. In this sense there is a creativity of the human brains."
} 
In order to analyse the development, the actions of the individuals are regarded first. These actions are explained with respect to the situation the individual meets with, and with the assumption of subjective rationality as far as the selection of alternative actions is concerned. The given situation is grasped by the description of the individual goals and the individual restrictions which counteract the achievement of the goal. Finally, the connection of the action of different individuals helps to understand the phenomenon as a whole.

From typical goals and individual restrictions typical patterns are derived which can be joined in a network of interactions with an evolutionary character. To a certain degree the individual restrictions are influenced by the actions of other individuals at the same time.

\section{The Individual as Politician}

The creation of a political subsystem as a representative democracy demands representatives with the power of decision instead of the single members of a collective body (Daumann, 1993, pp. 150). The parliament serves as legislative committee in which all representatives are put together. Changes of the given legal order require the consent of the majority of the members of parliament and must be compatible to the constitution. The representatives are designated by election in which they must gain the absolute majority in their local area; furthermore the elections must be held periodically, i.e. after the end of a certain period of time ${ }^{9}$.

The representatives as main actors in the political process and the candidates for such a post are to be called politicians (Kirsch, 1974, p. 71).

Since the representatives usually join hands to form groups of the same conviction, i.e. parties, and since the government is formed by a party or a coalition of parties, the principle of mutual control of power of government and legislation only plays a subordinate role. For the following analysis this means that the influence of the government corresponds to the influence of the majority of parliament and that therefore an analysis with a strict separation of government and legislation is not required. Besides that, the problems of the implementation of legal standards that result from the process of bureaucracy are excluded as well.

\subsection{The Goals of a Politician}

The urge of the individual as a politician to satisfy his needs is expressed by the aim of reaching or keeping a political office, i.e. in this context a seat in a parliament. On the one hand the occupation of a political office serves to attain money which can be used to satisfy monetary needs, on the other hand it helps to achieve esteem and power 10 .

The target of a politician does not require any further explanation beyond the statement that the politician aims at the occupation of a political office. Therefore the additional goals can remain individually shapeable and indefinite.

\subsection{Restrictions of the Actions of a Politician}

The participation of a politician in the legislative process has an instrumental character as far as his goals are concerned because advantages shaped as public disbursements and given to the clients of the politician have to be backed up by laws. There are restrictions which limit the actions of the politician upon the achievement of a political office as well as restrictions that limit his protection and occupation.

Thus the resources used in the election campaigns gain special importance in the process of attaining a political office. The requirements of the legislative procedure are found to be to be restrictions of the actions committed in order to protect the political office. The restrictions can be divided into formal and material restrictions, no matter which state of action the politician is in; in this essay only those restrictions which are important in this context are dealt with.

\footnotetext{
${ }^{9}$ The theory of elections was explained by Herder-Dorneich(1980).

${ }^{10}$ Downs (1957, p. 28) assumes that politicians "... solely act in order to attain the income, prestige, and power which come from being in office. Thus politicians in our model never seek office as a means of carrying out particular policies; their only goal is to reap the rewards of holding office per se. They treat policies purely as a means to the attainment of their private ends, which they can reach only by being elected."
} 


\subsubsection{Formal Restrictions}

The politician finds formal restrictions especially in the type of the constitution which determines the organization of the state and which is designated to protect certain basic rights in the process of legislation.

The law of the organization of the state gives two restrictions to the actions of the politician. Firstly, the individual must meet certain personal requirements if he wants to become a politician. Often it is necessary to be of a certain minimum age or to fulfil other criteria such as nationality ${ }^{11}$ etc. in order to be able to be elected (passive right of election).

Furthermore, there are restrictions which result from the law on the organization of the state as far as the process of legislation is concerned. The majority in the legislative committee is required in order to passlaws ${ }^{12}$. The politician needs a certain number of supporters among the politicians in order to enforce changes of the legal system.

Besides that, the actions of the politician are restricted by the constitution which has requirements on the contents of the laws which are to be passed 13 . This means that the constitution guarantees individual basic rights against which single laws may not infringe and which must be considered as far as the contents of new laws are concerned.

In this place the constitution of the Federal Republic of Germany (the so-called Grundgesetz) may serve as an example ${ }^{14}$; besides chartered freedom 15 it guarantees rights of equality 16 and basic rights of a fair trial ${ }^{17}$. Some of these rights cannot be changed at all ${ }^{18}$, others can be restricted only on the base of a simple law ${ }^{19}$ which however does not change the main content of the basic right concerned 20 . The relative limitation of features which cannot be used as an instrument of discrimination gives enough space for targeted actions to the politician although the variability of the constitution is very small.

\subsubsection{Material Restrictions}

Besides the amount of resources that can be employed in the election campaign the actions of the politician are limited also by the appearance of other candidates and by the state budget that can be distributed $^{21}$.

There is only a limited number of political offices because of the organization of the state as a representative democracy. Since several individuals are interested in occupying a political office

${ }^{11}$ The German law requires a minimum age of 18 years and the status of a German citizen for at least 1 year for a candidate to be nominated; see $\S 15$ BWG.

${ }^{12}$ The process of issuing federal laws sometimes requires the agreement of the Federal Council; for further details concerning the process of legislation see Hesse (1999, pp. 216).

${ }^{13}$ The German laws demand obligation to the basic rights for the three powers, see Grundgesetz, Art. 1, Abs. 3.

${ }^{14}$ Kimmel (2005) gives a comparison of the basic rights granted by the constitutions of EU-countries.

${ }^{15}$ I.e. freedom of faith, freedom of opinion, freedom of assembly; see Grundgesetz, Art. 4, 5, 8, 9.

${ }^{16}$ The Grundgesetz particularly claims equal justice under the law, equal rights for both sexes and the prohibition of discriminationon the basis of certain personal features; see Grundgesetz, Art. 3.

${ }^{17}$ Part of this basic right is, for example, free access to the law according to the Grundgesetz, Art. 19, Abs. 4.

${ }^{18}$ This is, for example, the human dignity which cannot be restricted at all, even if a qualified majority is in favour of a change of the constitution. The same is true for the freedom of faith, the freedom of assembly etc. There are similar basic rights that cannot be changed by simple laws in the constitutions of othercountries. So the first amendment of the American constitution forbids the congress to issue laws which restrict the freedom of speech, the freedom of the press, or the freedom of assembly.

${ }^{19}$ This is true for the personal freedom and the postal secrecy; see Grundgesetz, Art. 2, 10.

${ }^{20}$ See Grundgesetz, Art. 19: "In no case the character of a basic right may be changed."

${ }^{21}$ Beside these restrictions further limitations can occur as far as personal capabilities of the politician etc. are concerned; these restrictions however are not discussed in this place. 
competitive situations can be observed. The occurrence of competitors is perceived by the individual as a material restriction shaped as conciseness of political offices.

The successful candidature for a political office demands the reduction of the lack of information of potential voters as far as the candidate and his programme are concerned. The removal of these deficits of information and the gain of voters demand resources, which must be spent by the politician or provided to him by other individuals.

Each politician however has only limited and individually differing resources at his disposal which he can use in the election campaign in order to occupy a political office. On the one hand the individual budget is not inexhaustible even if the politician joins a party and has access to its funds. On the other hand the donations given by other individuals are limited, too.

As a consequence of exercising a political office in the legislative committee, the politician can use parts of the governmental budget according to the preferences of his voters. The amount of the state budget is mainly determined by the construction of the tax laws and by the debt management of the state. An enlargement of the disposable budget can result from an appropriate design of tax rates as a consequence of the economic development, or it can be arranged deliberately by changes of the tax laws 22 .

Thus the limitation of the state budget is a material restriction of the actions of the politician because it confines the preferential treatment of certain voters as far as the direct redistribution is concerned. Furthermore, the interrelation between preferred and discriminated individuals becomes obvious which might turn out to be counterproductive for the goals of the politician (Meier, A., Durrer, K., 1992, p. 252f.).

\subsection{The Actions of a Politician}

\subsubsection{The Problems involved in Uttering Personal Preferences}

In order to reach his goals, i.e. the attainment of a political office, the politician needs the majority of votes in his local area (Daumann, 1993, pp. 156). In this context the politician expects especially those voters to give their votes to him whose needs will be satisfied the best by him. Therefore the politician needs knowledge of the desires of the voters and of his clients in particular in order to act in a targeted way 23 .

The phenomenon of constitutional ignorance forces the individual to make efforts in gaining and analysing information if he wants to act successfully. The politician will endeavour to get data about the desires of his potential voters which are relevant for his action; then he will interpret this data subjectively and derive subjectively rational patterns of action. With the application of these patterns which have to be seen as transformation and assimilation of the interpreted data, the politician will try to offer better alternatives for the voters than his competitors.

Therefore the success of a politician depends upon his capability to understand the desires of the voters in a way which is superior to that of his competitors, to interpret these desires, and to transpose them into plans of action and into actions.

\subsubsection{Actions Directed Towards Achieving a Political Office}

In order to reach a political office, the politician must gain the necessary majority of voters by means of promising preferential treatment which will be provided by issuing corresponding laws. Besides the necessity of gaining information of the desires of the addressed voters the candidate for a political office must show to which extent he plans to satisfy the desires of the voters.

The voter considers cost and utility with respect to his vote. The decision of the voter is determined by the cost of information involved in generating different alternatives and selecting that alternative

\footnotetext{
${ }^{22}$ Progressive rates of income tax lead to an increasing average tax burden if the nominal income rises.

${ }^{23}$ The different mechanisms used to reveal individual preferences for public goods are described by Windisch(1981).
} 
which subjectively promises to be most advantageous and by the utility of voting. For the voter the amount of utility of voting depends upon the probability that his vote is decisive for his chosen candidate to succeed 24 .

In this stage the politician will try to reduce the information cost of the voters by intense advertising and by providing information to them free of charge. The free information however is limited by the amount of resources kept available for the election campaign of the candidate. The suggested interdependence of cause and effect, i.e. that the amount of resources provided for the election campaign correlates positively with the amount of votes given to that candidate, induces the politician to bypass this material restriction. An extension of this restriction results from donations of individuals who seek to enlarge their influence on the legislative process beyond their votes 25 .

Therefore the success of the candidate in achieving a political office is determined mainly by the supply and interpretation of the data on the desires of the voters and the design of an agenda of measures which have to be realized in the legislative process; besides that, the implementation of these measures has to be favourable and should reliably be perceived by the voter. Finally, the politician has to be capable to get access to the necessary resources for his election campaign and to apply these resources in a reasonable way.

The methods of perceiving information, the design of the agenda for the election campaign, and the exploitation of the resources of the election campaign can be regarded as approaches of innovative action. Creative ideas that go beyond the individually available potential of knowledge can lead to a more efficient use of the resources of the election campaign, or they can generate a more efficient perception of information; this potential of knowledge can be characterized by means-ends-relations which are subjectively valued correctly and checked individually or which have been delivered from history. Because of the implementation of creative fashioning the individual potential of knowledge experiences an irreversible change.

\subsubsection{Actions Directed Towards the Protection of a Political Office}

As soon as the politician has reached a political office in a legislative committee, he has the chance to patronize his clients in order to increase the probability of re-election. Direct support and indirect support are the means that a politician can apply in order to give preferential treatment to his clients. In addition, there are other possibilities of patronizing which are however of subordinate importance 26 .

Direct support can be shaped as social transfers (Albers, 1977; Andel, 1999, pp. 250; Brümmerhoff \& Büttner, 2015, pp. 308), subsidies, tax privileges (Hansmeyer, 1977; Andel, 1999, pp. 250), or it can be shaped in terms of real value 27 . For the politician the problems involved in direct support consist in the fact that the voter believes to look through the presumed effects of distribution; the voter however certainly neglects the whole phenomenon of incidence (Brümmerhoff \& Büttner, 2015, pp. 319) as far as the construction of his simple model of explanation is concerned. For the politician the evidence of the process of redistribution complicates the increase in votes because he loses the votes of those voters who are discriminated against by such are distribution. Furthermore the limitation of the state budget turns out to be a restriction because its expansion by means of fiscal charges or

\footnotetext{
${ }^{24}$ A fundamental explanation of the decision making process was given by Downs (1957, pp. 260); see also Mueller (1979, pp. 120), and Kirsch (1974, pp. 79).

${ }^{25}$ In this context pressure groups play a dominant role. On the one hand they have at their disposal information on the needs of their members and on the other hand they are able to support the politician in his election campaign financially or by means of other resources. See Frey (1981, p. 185), and Bernholz \& Breyer(1984, pp. $353)$.

${ }^{26}$ Other means of preferential treatment can result from the actions of the administration whose target is supposed to be the enlargement of its budget and of its discretionary manoeuvring room. See Niskanen(1971), Frey (1979, pp. 156), Blankart (2011, pp. 544), and Bernholz \& Breyer(1984, pp. 337).

${ }^{27}$ I.e. especially the provision of public goods and merit goods; see Musgrave, Musgrave \& Kullmer(1984, pp. 60), Buchanan (1965).
} 
increased borrowing also becomes visible, and a critical value will be reached quickly 28 . As a consequence, this behaviour is sanctioned negatively by the voter. For the politician direct support turn out to be an instrument for attaining votes which is to be used in a reserved way, no matter if this support is designed in real terms of value or in a material way.

The attempt of bypassing the problem of visibility by means of direct support styled as the method of netting out 29 intensifies the limitation of the state budget. In order to compensate the reduction of fiscal charges induced by such support the individuals who have not been treated preferentially have to yield a higher burden of fiscal charges; these individuals however will apply their potential of sanctions as soon as they can identify the cause of the increase of fiscal charges. Furthermore, it is not sure if the support shaped by the method of netting out will be recognized as a direct support and honoured accordingly with respect to the politician.

Indirect support results especially from the creation of regulations which can be designed in different ways. The effects of distribution which result from the regulations mainly remain unknown so that it is difficult for the voters who have been discriminated against by a regulation to recognize the interdependence of actions or even to estimate the amount of redistribution. Mostly a small group of preferentially treated individuals faces a huge number of people discriminated against by the regulation concerned such that the discrimination remains underneath the point of tangibility and therefore is not perceived as such.

Furthermore, restrictions are recognized by potential competitors only with hesitation in case these restrictions are regulations designed to protect certain branches of business from competition. Potential competitors tend to have problems in articulating their interests because the intention to enter a certain market has not occurred at that point and besides that such an interest remains in an imaginary sphere and therefore cannot be evaluated in a monetary way. The problem of the articulation of interests of the potential competitors is the reason for the fact that interventions against such proposals remain undone even if the discriminatory character of such a regulation is recognized. So indirect support induced by regulations isfavourable for the politician in the sense that the preferentially treated individuals perceive the advantage as such and attribute them correspondingly whereas the individuals discriminated against usually cannot notice the discrimination. For the politician regulations serve as a means which can help to win votes without the danger of losing votes of individuals discriminated against.

Because of the lack of transparency of the effects of redistribution as far as the individuals discriminated against are concerned the politician will preferentially apply regulations as a means to patronize his voters (Frey, 1981, p. 192).

The actions of the politician which are derived from historic and proven means-ends-relations are supplemented by innovative actions if the politician is interested in protecting the occupied political office. The practical application of creative ideas shaped as advancing action of the politician allows him to be ahead of his competitors. The reaction of the voter in particular as evaluation of this innovation irreversibly enlarges the individual potential of knowledge of the acting politician and of those individuals who get knowledge upon this advancing action for themselves.

\section{Result: The Political Process as Evolutionary Process With A Competitive CHARACTER}

Similar to the process of competition in the economic subsystem the process which takes place in the political subsystem shows evolutionary elements 30 . The politician is forced by his goal, which is to gain or keep a political office, to find out the desires of his potential voters, or to generate new desires in them. The perception of information, its subjective interpretation, and the creative generation of new alternatives of action are prerequisites for the creation of an election programme; the contents of such a programme are decisive for the success of the politician. In this election programme the

\footnotetext{
${ }^{28}$ In this context resistance to taxation is a basic problem; see Downs(1965).

${ }^{29} \mathrm{An}$ example for this are tax privileges that lead to a reduction of the individual tax burden.

${ }^{30}$ See Fig. 1: The Political Process as an Evolutionary Process. The main ideas of competition as evolutionary process are explained by Wegner (1992). See also Daumann (1993, pp. 161).
} 
politician promises to give support to certain voters such that their votes are likely to be given to the politician. In this context a higher quality and quantity of information can lead to competitive advantages if a politician is more likely to fulfil the needs of his voters by means of his election programme than his competitors.

With his vote the voter possesses a potential of sanctions with which he can influence the actions of the politicians in a positive or in a negative way. Now the advance of a politician is exposed to the potential of sanctions of the voters directly; this advance can be characterized as the result of the creativity of the politician which appears to be a changed combination of action parameters subjectively experienced as a new one. If a positive sanction happens, i.e. the other candidates lose votes, they are forced to react because otherwise they have to be worried about their political offices. The politician perceives the withdrawal of votes only as an abstract signal. Neither it is known who received these votes nor by which processor by means of which action parameter the votes were accumulated. A successful reaction requires the search for relevant information on the cause of the displacement of votes on the basis of which strategies for a reaction can be built up.

The reaction of the politicians who lost votes will consist of an advance with which the displaced votes can be reoccupied and with that new votes can be achieved. Whereas imitation strategies might be successful as far as the taking over of the cost of information is concerned they do lack importance with respect to the design of the action programme because each voter has only one vote and therefore the programme of the politician must be superior to that of others in order to reach the goals. A successful advance again starts new processes of gaining information by means of the abstract signal of displacement of votes among the competing politicians.

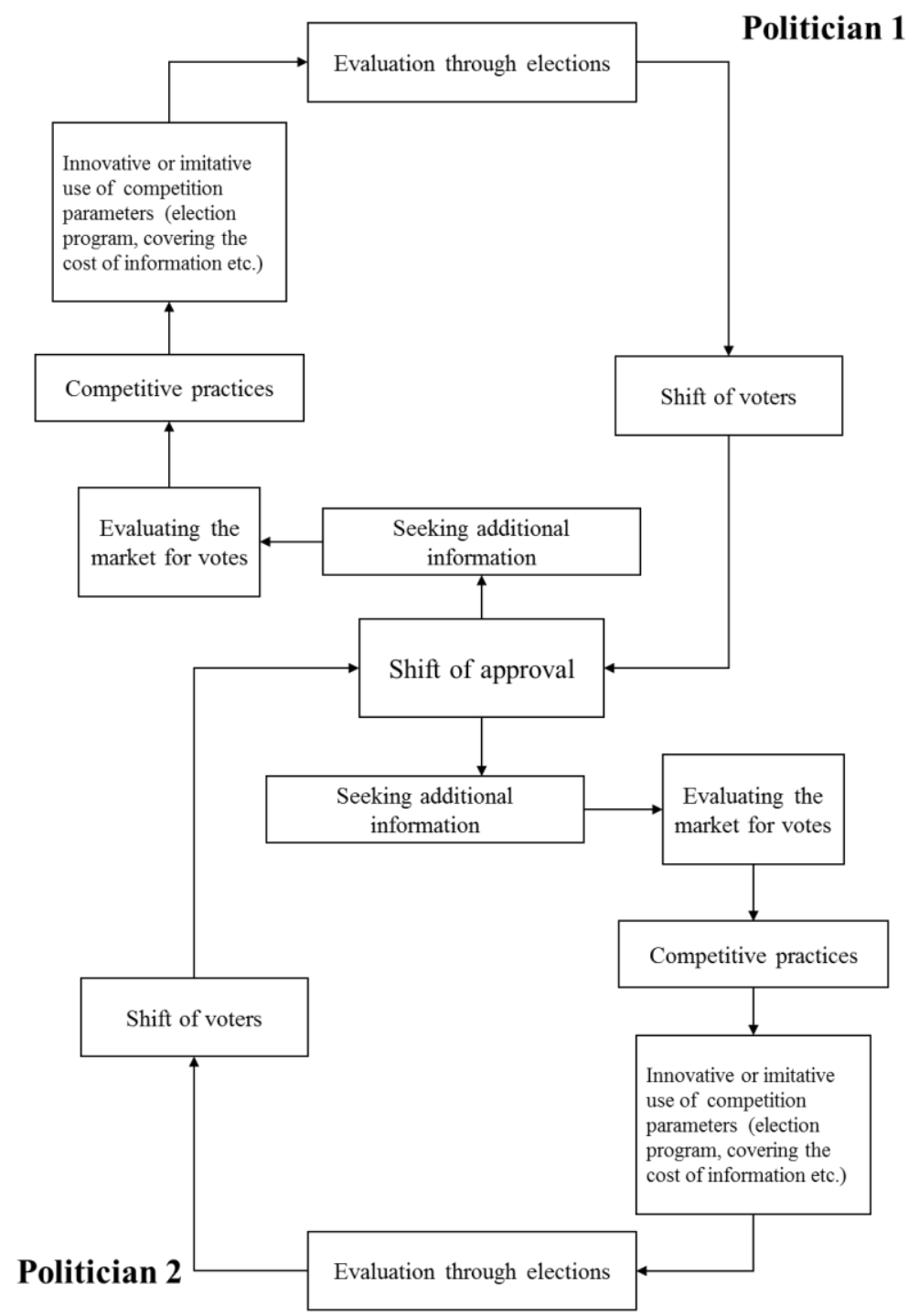

Figure1. The Political Process as an Evolutionary Process.

Source: Own illustration based on Dauman (1993, p. 167). 
If an advance of a politician fails because of a lack of acceptance among the voters this might cause the loss of the political office or a fruitless candidature.

The main difference between the competitive process in the political and in the economic subsystem consists in the procedure of applying sanctions in points of time. Whereas sanctions can take place in the economic subsystem at any time they happen in the political subsystem only before the beginning of a legislative period. The periodic repetition of the elections displaces the chance of sanctions of the voters into the future; therefore the evaluation of the capability of the politician to realize his programme in the legislative process becomes very important.

Beside the consideration of the needs of his clients, the restriction which results from the constitution and therefore limits the potential of measures is decisive for the shaping of the agenda of the politician. The constitution proves to be a restriction which is not easy to soften since changes of it are hardly feasible and a loose interpretation of the constitution might be sanctioned negatively 31 . The limitations given by the constitution however are very extensive such that a huge space of action remains for the politician.

The first step to satisfy the needs on a collective basis is accomplished with the election of the politician to the legislative committee. The chances to enforce parts of his own programme in the legislative process and therefore to change the legal order in a desired way depend on the success in achieving the necessary majorities for the single initiatives. The capabilities and the chances to get support from other politicians ${ }^{32}$ determine the success of the achievement of the programme ${ }^{33}$. Finally, the election of a politician who promises certain support for his voters cannot guarantee the fact that this support passes the legislative process and becomes law. In this situation however, the innovative impulse to change the legal order by the initiative of the politician and its acceptance by other politicians are decisive. Prerequisites for this are the fact that similar proposals can be found in the agenda of other politicians or that other politicians can be found whose clients are not discriminated against by these proposals and who expect support of their own proposals in return 34 .

The shape of the mechanism of the legislative process as a majority vote leads to the evolution of the legal order directed towards the introduction of elements which patronize certain voters in a hidden way. Innovations in the political process will be particularly successful if the principle of redistribution which must remain hidden and unperceivable for the individuals discriminated against is brought to perfection. Furthermore, the exchange of votes has the effect that the amount of donations given only to a limited group of voters and supported by little funds of the majority of other voters constantly grows.

The tendency of hidden discrimination and of incorporation of demands of groups that know how to articulate their desires in the election programme remains present because the constitution turns out to be an extensive restriction, and moreover the budget hardly becomes a restriction for the actions of the politicians as far as measures of indirect distribution are concerned 35 . The development of the legal order steadily appears shaped as new variations of the laws with increasingly subtle mechanisms of support.

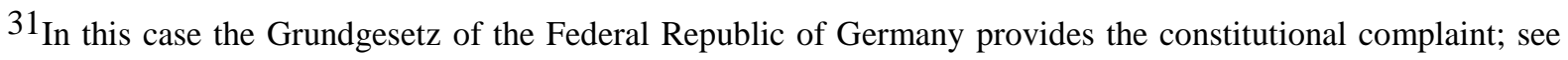
Grundgesetz, Art. 93.

${ }^{32}$ Usually there will be a consensus upon the laws which are to be implemented. In addition, compromises can be found and it remains the chance of exchanging votes. See Buchanan (1975, pp. 134), and Bernholz (1979).

${ }^{33}$ Other determinants of the success of the achievement of the programme are explained in the cognitiveevolutionary model of Meier \&Durrer(1992, pp. 239).

${ }^{34}$ In most representative democracies however the legislative process is determined by parties that limit the free mandate by voting by whip and therefore accomplish a preselection and bundle of proposals to change the legal order.

${ }^{35}$ The effects of indirect measures of distribution styled as regulations on the state budget arise because of the fact that they hinder the structural change and therefore prevent growth; see Hamm(1978, p. 73).
} 
This process does not adhere to a cogent regularity because innovative politicians may uncover the mechanism of redistribution and include its reduction in their programme. However it is doubtful if these politicians will be successful 36 .

The evolution of the political process does not only cover the legal order, beside that innovations and imitations may include all action parameters that the politician has access to. So the politician can apply creative ideas to obtain information as well as to take over the costs of information of the voter.

Voters whose needs have not been considered sufficiently in the political process because of their interests being difficult to articulate might be confronted with the situation that because of the legislative process, they have to carry burdens from which other groups profit that know better how to articulate their desires.

Therefore the political process enriches the legal order with elements that show discriminating effects and that restrict the freedom of certain individuals. Consequently, a legal order which counteracts the original intention of collective decisions and the liberal ideal of a constitutional state results from the political process. Besides that, this development leads to a limitation of free economic actions which on the other hand slows down innovative actions of the entrepreneurs and therefore also delays the economic growth.

\section{REFERENCES}

[1] Albers, W. (1977). Transferzahlungen an Haushalte.In F. Neumark,N. Andel\&H Haller (Eds.), Handbuch der Finanzwissenschaft(Bd. 1, 3th ed., pp. 861-957).Tübingen: Mohr-Siebeck.

[2] Andel, N.(1999).Finanzwissenschaft (4th ed.). Tübingen: Mohr-Siebeck.

[3] Arrow, K. J. (1963).Social Choice and Individual Values (2nd ed.).New York:Wiley.

[4] Bernholz, P.(1979). Stimmentausch, Arrow-Paradoxon und zyklische Majoritäten.In: W. W. Pommerehne, \& B. S. Frey (Eds.), Ökonomische Theorie der Politik(pp. 171-179). Berlin, Heidelberg, New York: Springer.

[5] Bernholz, P.\& Breyer, F. (1984).Grundlagen der Politischen Ökonomie(2nd ed.). Tübingen: MohrSiebeck.

[6] Blankart, C. B. (2011). Öffentliche Finanzen in der Demokratie (8th ed.) . München: Vahlen.

[7] Brümmerhoff, D. \& Büttner, T. (2015). Finanzwissenschaft (11th ed.). München, Wien: Oldenbourg.

[8] Buchanan, J. M. (1965). An Economic Theory of Clubs. Economica, 32,1-14.

[9] Buchanan, J. M. (1975).The Limits of Liberty. Between Anarchy and Leviathan. Chicago, London: The University of Chicago Press.

[10] Buchanan, J. M. \&Tullock, G. (1975).The Calculus of Consent. Logical Foundations of Constitutional Democracy(5th ed.).Ann Arbor: University of Michigan Press.

[11] Daumann, F. (1993). Zur Notwendigkeit einer Harmonisierung im Gemeinsamen Markt. Bayreuth: P.C.O.

[12] Downs, A. J. (1957).An Economic Theory of Democracy, New York: Harper \& Row.

[13] Downs, A. (1965). Why the Government Budget Is Too Small in a Democracy.In: E. S. Phelbs (Ed.), Private Wants and Public Needs (2nd ed., pp. 76-95). New York: Norton.

[14] Eickhof, N. (1985). Wettbewerbspolitische Ausnahmebereiche und staatliche Regulierung.In: Jahrbücher für Sozialwissenschaft, 36, 63-79.

[15] Frey, B. S. (1979). Ansätze zur Politischen Ökonomie.In: W. W. Pommerehne\& B. S. Frey (Eds.),Ökonomische Theorie der Politik (pp. 1-34). Berlin, Heidelberg, New York: Springer.

[16] Frey, B. S. (1981).Theorie demokratischer Wirtschaftspolitik. München: Vahlen.

[17] Graf, H.-G. (1978)."Muster-Voraussagen" und "Erklärungen des Prinzips" bei F. A. von Hayek. Eine methodologische Analyse. Tübingen: Mohr-Siebeck.

\footnotetext{
36 Noll (1983, p. 401) says that the implementation of regulations already implements their abolishment because the effect of redistribution and the inefficiencies might alert political entrepreneurs who will make visible the problems involved. Now the success of this political entrepreneur depends upon the amount of losses of welfare and upon the shape of the distribution of these losses for the discriminated.
} 
[18] Hamm, W. (1978). Staatsaufsicht über wettbewerbspolitische Ausnahmebereiche als Ursache ökonomischer Fehlentwicklungen.In: ORDO - Jahrbuch für die Ordnung von Wirtschaft und Gesellschaft(Bd. 29, pp. 156-172). Stuttgart, New York: Gustav Fischer.

[19] Hansmeyer, K. H. (1977). Transferzahlungen an Unternehmen (Subventionen). In: F. Neumark,N. Andel\& H. Haller (Eds.), Handbuch der Finanzwissenschaft(Bd. 1, 3th ed., pp. 959-996). Tübingen: MohrSiebeck.

[20] Hayek, F. A. v. (1942).Scientism and the Study of Society.In: Economica, New Series, 9(35), $267-291$.

[21] Hayek, F. A. v. (1967).The Theory of Complex Phenomena.In: Hayek, F. A. v. (Ed.), Studies in Philosophy, Politics and Economics (pp. 22-42). London, Chicago, Toronto: Routledge and Kegan Paul.

[22] Hempel, C. G. (1977).Aspekte wissenschaftlicher Erklärung. Berlin, New York: de Gruyter.

[23] Herder-Dorneich, P. (1980). Der Beitrag der "Ökonomischen Theorie der Wahlen" zur "Neuen Politischen Ökonomie".In: E. Boettcher, P. Herder-Dorneich\& K.-E. Schenk (Eds.), Neue Politische Ökonomie als Ordnungstheorie (pp. 3-29). Tübingen: Mohr-Siebeck.

[24] Hesse, G. (1990).Evolutorische Ökonomik oder Kreativität in der Theorie.In: U. Witt (Ed.), Studien zur evolutorischen Ökonomik I (Bd. 195/1, pp. 49-73). Berlin: Schriften des Vereins für Sozialpolitik.

[25] Hesse, K. (1999).Grundzüge des Verfassungsrechts der Bundesrepublik Deutschland(20th ed.). Heidelberg: C. F. Müller.

[26] Hotelling, H. (1929).Stability in Competition.In: The Economic Journal, 34, 41-57.

[27] Jarvie, I. C. (1974).Die Logik der Gesellschaft. Über den Zusammenhang von Denken und sozialem Wandel. München: List Paul.

[28] Kimmel, A. (2005). Einführung.In: Die Verfassungen der EG-Mitgliedstaaten(6th ed., pp. IX-XIX). München: Beck.

[29] Kirsch, G. (1974).Ökonomische Theorie der Politik. Tübingen, Düsseldorf: J. C. B. Mohr.

[30] Koertge, N. (1975).Popper's Metaphysical Research Program for the Human Sciences.In: Inquiry, 18, 437462.

[31] Mayer-Tasch, P. C. (1975). Europäische Verfassungshomogenität als politisches Erbe.In: P. C. MayerTasch, \& I.Contiades. (Eds.),Die Verfassungen der nicht-kommunistischen Staaten Europas(2nd ed., pp. 1-36). München:Beck.

[32] Meier, A., Durrer, K. (1992). Ein kognitiv-evolutionäres Modell des wirtschaftspolitischen Prozesses.In: U. Witt. (Ed.), Studien zur Evolutorischen Ökonomik II(pp. 229-254), Berlin: Duncker \& Humblot.

[33] Mueller, D. C. (1979).Public Choice. Cambridge: Cambridge University Press.

[34] Musgrave, R. A., Musgrave, P. B., Kullmer, L. (1984).Die öffentlichen Finanzen in Theorie und Praxis(Bd. 1, 3th ed.).Tübingen: J. C. B. Mohr.

[35] Niskanen, W. (1971).Bureaucracy and Representative Democracy. Chicago, New York:Aldine Atherton.

[36] Noll, R. (1983).The Political Foundations of Regulatory Policy.In: Zeitschrift für die gesamte Staatswissenschaft, 139, 377-404.

[37] Olson, M. (1965).The Logicof Collective Action.Cambridge, Massachusetts, London: Harvard University Press.

[38] Popper, K. R. (1974). Das Elend des Historizismus (4th ed.). Tübingen: Mohr.

[39] Popper, K. R. (1969). Die Logik der Sozialwissenschaften.In: T. W. Adorno, et al. (Eds.), Der Positivismusstreit in der deutschen Soziologie (pp. 103-123). Neuwied, Berlin: Leuchterhand.

[40] Popper, K. R. (1980).Die offene Gesellschaft und ihre Feinde II. Falsche Propheten. Hegel, Marx und die Folgen (6th ed.). Tübingen: Francke.

[41] Popper, K. R. (1967). La rationalité et le statut du principe de rationalité.In: E.-M. Claassen (Ed.), Les fondementsphilosophiques des systèmeséconomiques(pp. 142-150).Paris: Payot.

[42] Popper, K. R. (1973). Zur Theorie des objektiven Geistes.In: K. R. Popper (Ed.) Objektive Erkenntnis(2nd ed., pp. 172-212).Hamburg: Hoffmann \&Campe.

[43] Schumpeter, J. A. (1942).Capitalism, Socialism and Democracy. New York: Harper \& Row.

[44] Vanberg, V (1975). Die zwei Soziologien. Individualismus und Kollektivismus in der Sozialtheorie. Tübingen: Mohr.

[45] Watkins, J. W. N. (1952/53).Ideal Types and Historical Explanation.In: The British Journal for the Philosophy of Science, 3, 22-43.

[46] Watkins, J. W. N. (1978).Unvollkommene Rationalität.In: J. W. N. Watkins, Freiheit und Entscheidung(pp. 29-87). Tübingen:Mohr. 
[47] Weber, M. (1973). Über einige Kategorien der verstehenden Soziologie.In: M. Weber, Gesammelte Aufsätze zur Wissenschaftslehre(4th ed., pp. 427-474). Tübingen: Mohr.

[48] Weber, M. (1976).Wirtschaft und Gesellschaft, Grundriß der verstehenden Soziologie(5th ed.). Tübingen: Mohr.

[49] Wegner, G. (1992). Wissensnutzung in Märkten. Zur Unvereinbarkeit von Ordnungstheorie und Gleichgewichtstheorie. In: Jahrbücher für Sozialwissenschaft, Bd. 43, 4-64.

[50] Windisch, R. (1981). Das Anreizproblem bei marktlicher Koordinierung der Nutzung knapper Umweltressourcen. In: L. Wegehenkel (Ed.), Marktwirtschaft und Umwelt(pp. 105-149). Tübingen: Mohr.

[51] Witt, U. (1987).Individualistische Grundlagen der evolutorischen Ökonomik. Tübingen: Mohr.

Citation: Frank Daumann. "A Model Based on the Theory of Evolution as a Means of Explaining the Political Process in Democracies" International Journal of Managerial Studies and Research (IJMSR), vol 6, no.4, 2018, pp. 31-43. doi:http://dx.doi.org/10.20431/2349-0349.0604004.

Copyright: (C) 2018 Authors. This is an open-access article distributed under the terms of the Creative Commons Attribution License, which permits unrestricted use, distribution, and reproduction in any medium, provided the original author and source are credited. 